\title{
Causal Agents of Mycobacterial Diseases in Freshwater Ornamental Fish and their Importance for Human Health in the Czech Republic
}

\author{
J. ŘEHULKA ${ }^{1}$, J. KAUSTOVÁ ${ }^{2}$, E. ŘEHULKOVÁ ${ }^{3}$ \\ ${ }^{1}$ Department of Zoology, Silesian Museum, Opava, ${ }^{2}$ National Reference Laboratory for Mycobacterium \\ kansasii, Regional Institute of Public Health, Ostrava, ${ }^{3}$ Department of Zoology and Ecology, \\ Faculty of Science, Masaryk University, Brno, Czech Republic
}

Dedicated to the $80^{\text {th }}$ birthday of Prof. MVDr. Z. Lucký, CSc., Professor Emeritus of the Department of Game, Fish and Bee Diseases, University of Veterinary and Pharmaceutical Sciences, Brno, Czech Republic

\section{Received September 15, 2005 \\ Accepted March 16, 2006}

\begin{abstract}
Řehulka J., J. Kaustová, E. Řehulková: Causal Agents of Mycobacterial Diseases in Freshwater Ornamental Fish and their Importance for Human Health in the Czech Republic. Acta Vet. Brno 2006, 75: 251-258.

In the period from 1995 to 2004, the following mycobacterial species were isolated during the examination of the state of health of aquarium fish from the Moravian-Silesian region of the Czech Republic: Mycobacterium fortuitum (Paracheirodon axelrodi, Poecilia sphenops, Hemigrammus rhodostomus, Hyphessobrycon flammeus), M. chelonae (P. axelrodi, Betta splendens, Xiphophorus helleri, Puntius tetrazona), M. kansasii (P. axelrodi, B. splendens), M. simiae (Hyphessobrycon ecuadoriensis), and M. gordonae (P. axelrodi, Colisa lalia, B. splendens, Symphysodon discus). The first isolation from aquarium fish was recorded in the case of $M$. kansasii and the second isolation in the case of $M$. simiae; both should also be taken into account as aetiological agents of mycobacterial infections in humans. The measures to reduce mycobacterial infections in both fish and humans should include monitoring water mains as possible sources of $M$. kansasii infections, compliance with the sanitation principles in handling fish suspected of being infected and the content of tanks (molluscs, water, plants), and the introduction of strict veterinary inspection of imported fish, fish from aquarist shops and from large-scale distributors.
\end{abstract}

Zoonosis, mycobacteriosis, "fish-tank" granuloma, Mycobacterium fortuitum, M. chelonae, M. kansasii, M. simiae, M. gordonae

Identification of the causal agents of bacterial diseases in aquarium culture is an important part of the health care of ornamental fish, aimed at reducing infections and minimising losses. This applies, in particular, to conditions where ornamental fish are reproduced on a mass scale and therefore, where the probability of an outbreak of epizooties of bacterial aetiology is very high. In addition to the much feared causal agents of acute bacterial diseases, attention must also be paid to the agents causing chronic conditions, including, in particular, mycobacterial infections. According to Mátlová et al. (1998), there are more than 70 (and by the latest data already more than 90) known mycobacterial species that can be classified by their relation to the host into obligate pathogens of vertebrates (Mycobacterium tuberculosis, M. paratuberculosis, M. bovis) and potentially pathogenic mycobacteria, which include the majority of mycobacteria potentially pathogenic for the poikilotermic animals (M. marinum, M. chelonae and M. fortuitum).

The first case of mycobacteriosis in freshwater fish was described by Bataillon et al. (1987) in the common carp (Cyprinus carpio): the authors named the isolated bacteria M. piscium. According to literature, mycobacterioses belong to the most common chronic diseases of both freshwater and marine fish all over the world, particularly in the regions of

Address for correspondence:

Doc. Ing. J. Řehulka, CSc.

Slezské zemské muzeum

Nádražní okruh 33

74601 Opava, Czech Republic
Phone: +420553628660

Fax: +420 553622999

E-mail: jiri.rehulka@szmo.cz

http://www.vfu.cz/acta-vet/actavet.htm 
the temperate and tropical zone. Ippen (1964) states that mycobacterial infections have been described to occur in 10 orders, 85 genera and 123 species of freshwater and marine fish, and according to Nigrelli and Vogel (1963) they have been described in 151 fish of 34 genera from different geographical regions. However, the occurrence of mycobacterial infections is most common in aquarium fish, where they rank among the most dangerous health problems with unfavourable prognosis.

Jahnel (1940ab) described findings of mycobacteria in the following species: black tetra (Gymnocorymbus ternetzi), pearl danio (Danio albolineatus), spottedsail barb (Puntius phutunio), malabar danio (Devario malabaricus), Egyptian mouth-brooder (Pseudocrenilabrus multicolor multicolor), bloodfin tetra (Aphyocharax anisitsi), dwarf gourami (Colisa lalia) and representatives of the genus Xiphophorus. Although it is impossible to eliminate a disease entirely in its acute form, when fish dies with no external symptoms, systemic diseases regularly occur, affecting any organ with a typical granulomatous response in the advanced stages of the condition (Ippen 1964; Wolke 1975; Wolke and Stroud 1978; Majeed et al. 1981; Csaba et al. 1982; Noga et al. 1990). Much attention was paid to mycobacterioses by Amlacher (1986). In his monograph about fish diseases, he states that 71 species of aquarium fishes are susceptible, and provides documentation concerning macro- and microscopic findings in 9 species of ornamental fishes. The causative organism of mycobacteriosis in the goldfish (Carassius auratus) and redeye tetra (Moenkhausia sanctaefilomenae) in Malaysia was characterised on the basis of examining its biochemical and physiological properties. The isolate differed in many characteristics from the reference strains of $M$. chelonae subsp. chelonae and $M$. chelonae subsp. abscessus as well as the rapidly growing photochromogenic M. parafortuitum and M. vaccae (Shamsudin et al. 1990).

As for the species of more recent description, mention should be made of $M$. poriferae in the snakehead murrel (Channa striatus) (Tortoli et al. 1996). Skin ulcers and fin damage due to mycobacterial infection have been previously reported in aquarium fish (Richard s 1977; van Duijn 1981). Not even some salmonid fishes have escaped mycobacterial infections. Wood and Ordal (1958) reported a very high incidence of mycobacterioses in hatchery-reared Pacific salmon and steelhead trout fed ground, uncooked viscera of adult fish infected with mycobacteria.

Serology of M. chelonae isolated from salmonids (Salmo clarkii, Oncorhynchus kisutch, O. tshawytscha, Prosopium williamsoni) was performed by Arakawa et al. (1986). Interestingly, cutaneous mycobacteriosis was found in the common carp (Majeed and Gopinath 1983) and in yellow perch ( Perca flavescens) (Daoust et al. 1989).

On the Czech territory, the first cases of mycobacterium infection were described by Lucký and Vaněk (1962) in the following aquarium fishes: Pearl gourami (Trichogaster leeri), blue gourami (T.trichopterus), green swordtail (Xiphophorus helleri), guppy (Poecilia reticulata), siamese fighting fish (Betta splendens), Agassiz' dwarf cichlid (Apistogramma agassizii) and giant gourami (Osphronemus gouramy).

Increasing occurrence of mycobacterial diseases in aquarium culture encourages the efforts of ichthyopathologists to detect the infectious agent and to enhance the knowledge of the sources of mycobacteria other than tuberculosis (MOTT). This is because the outcomes of experimental work indicate that water as a reservoir of certain mycobacterial species plays an important role in the epidemiology of mycobacterial infections caused by MOTT in people and animals (Eilertsen 1969; Ślosárek and Janota 1990).

The objective of the study was to provide information on current knowledge of the clinically important mycobacterial infections in aquarium fish from the Moravian/Silesian region of the Czech Republic with respect to the current growing interest in the issues of the occurrence of mycobacteria in poikilothermic animals and humans (Mátlová et al. 1998). 
Fish

\section{Materials and Methods}

Over the past decade, as many as 186 freshwater ornamental fish of 74 species have been delivered to our laboratory for an examination of the cause of disease. Most of the fish came from small breeders and from larger reproduction facilities, but some also came from aquarium fish shops and hobby breeders. Post mortem examinations were carried out according to Lucký (1982), Roberts and Shepherd (1997), Austin and Austin (1987), Ergens and Lom (1970), and Lom and Dyková (1992).

Bacteriology

The bacteriological procedures involved Gram staining of tissue smears, cultivation on growth media and evaluation of microbial cultures. Blood agar (Columbia Agar Base MERCK), cytophaga agar (Anacker and Ordal 1959), tryptone soya agar (TSA, Oxoid) and sweet wort agar (Fas satiová 1979) served for the cultivation.

Mycobacteriological examination

The samples were decontaminated by modified Petroff method with $1 \mathrm{M} \mathrm{NaOH}$ solution. From the sediment two smears were prepared for Ziehl-Neelsen and fluorochrome staining. Sediment was inoculated onto 3 Löwenstein Jensen media. Two of them were incubated at $37^{\circ} \mathrm{C}$ and one at $30^{\circ} \mathrm{C}$. Where acid-fast bacilli (AFB) were found, the strain was identified either by means of the GENProbe chosen on the basis of macro- and microscopic morphology of the strain, or by conventional methods based on growth characteristics: temperature tolerance, colony and cell morphology, growth rate, pigment production and biochemical properties.

Susceptibility to streptomycin (STM), isoniazide (INH), rifampicin (RIF), ethambutol (EMB), ciprofloxacin (CIP), gentamicin (GEN) and clarithromycin (CLA) in vitro was determined in the Sula liquid medium, using the minimum inhibitory micro-method (MIC).

Susceptibility to pyrazinamid (PZA) was determined on the Löwenstein Jensen medium by the proportional method at a concentration of $400 \mathrm{mg} / \mathrm{l}$.

Sampling procedure for histopathology

Histology of the skin, gills, skeletal muscle, heart, liver or hepatopancreas, spleen, kidney, brain and digestive tract samples were fixed in Davidson's alcohol-formaldehyde-acetic acid solution, embedded in paraffin, sectioned at $5 \mu \mathrm{m}$ and stained with haematoxylin and eosin (H\&E), Mason trichrome, the periodic acid - Schiff (PAS), Giemsa, Gram and Ziehl-Neelsen methods.

\section{Clinical data}

\section{Results}

Cases of fish symptoms of tuberculous nature occurred in the following fish species: Sumatra barb (Puntius tetrazona), Siamese fighting fish, flame tetra (Hyphessobrycon flammeus), Columbian tetra (Hyphessobrycon ecuadoriensis), kissing gourami (Helostoma temnincki), cardinal tetra (Paracheirodon axelrodi), black tetra, guppy, neon tetra (Paracheirodon innesi), goldfish, green swordtail, dwarf gourami, discus fish (Symphysodon discus), angelfish (Pterophyllum scalare), rummy-nose tetra (Hemigrammus rhodostomus), garnet tetra (Hemigrammus pulcher) and red piranha (Serrasalmus nattereri) .

Microscopically, we described the causal agents of the disease as short and slightly bent acid-fast bacilli, Gram-positive rods concentrated in the granulomas or, to a lesser extent, dispersed outside the granulomatous foci. These findings encouraged us to provide a cultivation proof of mycobacteria for the purpose of identifying their species. From 1995 to 2004, we isolated mycobacterial strains from the clinical material in the following ornamental fish species: cardinal tetra, (M. fortuitum, M. chelonae, M. kansasii, M. gordonae), dwarf gourami (M. gordonae), Siamese fighting fish (M. chelonae, M. kansasii, M. gordonae), black molly (Poecilia sphenops) (M. fortuitum), green swordtail (M. chelonae), Sumatra barb (M. chelonae), discus fish (M. gordonae), rummy-nose tetra ( $M$. fortuitum), flame tetra ( $M$. fortuitum), and Columbian tetra (M. simiae).

The diseased fish showed increased susceptibility to infection by other pathogenic bacteria (Aeromonas hydrophilla, A. caviae, A. sobria, Plesiomonas shigelloides, Micrococcus luteus, Staphylococcus epidermidis), or protozoan parasites (Spironucleus elegans) and monogeneans (Gussevia spiralocirra, Sciadicleithrum imphthimum, S. varabilum) in the angelfish and discus fish. 
Major clinical signs and histopathologic features

Diseased fish exhibited clinical signs including: loss of appetite, lethargy, staying alone in the corner of the aquarium, floating on the surface of the water, cachexia, depigmentation, severe exophthalmos, ascites, erection of scales, loss of scales, skin ulcers, and fin damage.

Histologically, it was mainly in the kidney, spleen and liver that we observed focal granulomas in varying stages of development, with a necrotic centre. They were surrounded by layers of macrophages and epitheloid cells with pronounced fibrosis on the periphery. The granulomas were packed with acid-fast bacili (Plate VII and VIII, Fig 1abcd). In some cases granulomatous inflammation was observed in the lamelae tissue of the gills, brain, and heart, and within skeletal muscle. The exudative form of reaction was not uncommon, in addition to the productive form of the disease, characterised by a specific proliferating inflammation with the formation of granulomas.

\section{Microbiology}

Identification of M. kansasii was performed by means of GEN Probe M. kansasii (with a negative result) and, in parallel, by conventional identification methods. The results of testing by the conventional identification methods corresponded to the properties of M. kansasii, including the negativity of the diaminooxidase test, which is otherwise positive in the photochromogenic M. marinum. It can be judged from these results that what was identified was not M. kansasii subspecies I or V, described by Picardeau et al. (1997) and Alcaide et al. (1997) on the basis of a hsp65 PCR-RFLP analysis. Of the five types of $M$. kansasii described by these authors, types I and II constitute frequent clinical isolates. $M$. kansasii type I, generally identified by a positive AccuProbe test, is the most frequent $M$. kansasii isolate from human sources worldwide. In contrast, type II is frequently isolated from both humans and the environment, and it is characterised by negative hybridisation to the AccuProbe. Types III, IV, and V were rarely isolated from humans, but were present in environmental samples, most frequently from tap water (Alcaide et al. 1997; Picardeau et al. 1997).

NRL for M. kansasii identifies the strains of $M$. kansasii isolated from samples taken from patients by the tAccuProbe identification methods, and so it can only be stated again that the strain isolated from the cardinal tetra was not M. kansasii subsp. I or V.

The values of MICs in mg/l: $(\mathrm{S}=$ sensitive, $\mathrm{R}=$ resistant): STM 0.5 - S, INH 2.0 - R, EMB 1.0 - S, RIF 0.13 - S, CIP 0.5 - S, GEN 2.0 - S, CLA 0.5 - S, PZA - R. The sensitivity of this strain was similar to that of the strains of this species isolated from humans in northern Moravia. Resistance to INH corresponds to the MIC value recorded in the majority of patients. Resistance to PZA is up to $10 \%$ in the strains isolated from the samples taken from the inhabitants of the North Moravian region.

\section{Discussion}

Our findings enhanced the knowledge of mycobacterioses of aquarium fish. Lucký and Vaněk (1962) were the first to draw attention to these mycobacterioses. We consider important our finding of $M$. kansasii, which has not yet been isolated anywhere else from fish, and also $M$. simiae, which has so far only been isolated from the black acara (Cichlasoma bimaculatum) (Lansdell et al. 1993). A finding of M. fortuitum on the territory of former Czechoslovakia is described by Vasilová (1988) in the diseased representatives of the genus Xiphophorus of undetermined species. Bragg et al. (1990) isolated M. fortuitum from three species of freshwater fish: from oscars (Astronotus ocellatus), guppies and discus fish (Symphysodon aequifasciatus). Pathogenicity of 
M. fortuitum for goldfish is described by Talaat et al. (1999) and for the laboratory zebrafish (Brachydanio rerio) by Astrofsky et al. (2000).

$M$. chelonae is characterised by the ability to cause disease in a wide range of freshwater and marine fishes. In addition to infection in a number of aquarium fish species, there are also cases of mycobacterial infection in farmed turbot (Scophthalmus maximus) (Santos et al. 2003), in wild and captive delta smelt (Hypomesus transpacificus) (Antonio et al. 2000), in a population of yellow perch (D a ou st et al. 1989) and in salmonid fish (Arakaw a and Fryer 1984; Arakawa et al. 1986).

The therapy of mycobacterioses in fish has not yet been sufficiently developed and is impossible in advanced cases. Prevention plays an important role in controlling the infection, and it consists of adequate fish culture sanitation. In commercial aquarium fish breeding facilities, prevention includes regular veterinary inspection, which is necessary in both the imports of fish from abroad and in transport within the country. Differences in the rate of occurrence of mycobacterioses in aquarium fish are due to different predisposition of individual fish species to infection and different susceptibility to the action of external factors. As for those factors, it is necessary to minimise the stress to which the fish are often exposed when they are removed from their natural conditions to be put in aquaria.

Likewise, it is necessary to modify the physical and chemical properties of water if they are unfit for the fish. Long-term maintenance of high water temperatures should be avoided and fish food should be optimised in terms of balance between protein and fat components. According to Lucký (1978), suspected specimens should be removed and before an infested tank is restocked, its walls must be disinfected with chlorseptol (disinfectant based on chloramine, currently manufactured as 'Chloramin B' by Bochemie Bohumín, Czech Republic). Freshwater gastropods may be among the vectors of mycobacteria that may survive at the aquarium bottom for several days - it is therefore also recommended to replace the sand and plants in the tank (Paris ot and Wood 1966).

For sanitation reasons, it is important to take into account the possibility of the infection transmission to people. This mainly applies to professional fish breeders who are in everyday contact with the fish. Evidence is provided by Adamicová et al. (2003) who described a case of granulomatous lesion in a keeper's skin, caused by injury by a piranha in Slovakia. Although the authors did not prove it by the Ziehl-Neelsen AFB method, they found in some of the macrophages sporadic acid-fast microstructures, spherical in shape. The local finding on the skin of the patients and the histological examination of infection by the MOTT - swimming pool fish tank granuloma. In a number of cases, M. marinum is indicated as the aetiological agent in relation to skin lesions after injury by fish (Bowenkamp et al. 2001; Cassal and Cassal 2001; De la Torre et al. 2001; Chan et al. 2002; Kullavanijay a 1999; Palomo et al. 2001; Wu et al. 2002; Kaustová 2003). $M$. marinum belongs to slowly growing piscine and human MOTT, included in the group of photochromogenic mycobacteria responsible for skin lesions (Rubin and Farber 1988). The ultrastructure of M. marinum after intraperitoneally infected striped bass (Morone saxatilis) was studied by Gauthier et al. (2004). With respect to human health, attention must also be paid to the M. simiae and M. kansasii isolated by us. According to Lan sdell et al. (1993), numerous reports in literature confirm that $M$. simiae is commonly found in environmental water sources. In Israel, 399 strains were isolated from humans. Most of these were considered to have come from environmental sources, probably water. Wayne and Sramek (1992) isolated M. simiae from water supply of a hospital in Gaza, and How ard et al. (1987) from tap water in Arizona. M. simiae has been isolated from a patient with pulmonary infection in Germany (Krümmel et al. 1989). M. simiae was found in the sphagnum vegetation ( Sphagnum balfourianum) of Madagascar - it is the first isolation in the environment (Schröder et al. 1992). 
The finding of $M$. kansasii as the aetiological agent of pulmonary and/or also extrapulmonary disease in humans may be related with its endemic occurrence in both industrial water and drinking water in North Moravia (Kau stová et al. 1995; Martínková et al. 2001), i.e. in the region where we conducted our mycobacterial investigation. Contaminated water from water pipelines, on the walls of which MOTT proliferate, may be the source of $M$. kansasii infection, as indicated by the results of examination of both industrial water and drinking water (Kau stová et al. 1981; Martínk ová et al. 2001). The percent proportions of positive findings of $M$. kansasii was $33.4 \%$ in industrial waters and $6.8 \%$ in drinking water. Mycobacteriological monitoring of the water mains from which aquarium keepers take water should be an important measure to ensure a good health condition of the fish and a safe aquarium fish business.

\section{Conclusions}

It has been confirmed by many years of practical experience in the diagnostics of the health condition of aquarium fish that mycobacterial infections are a serious problem in both smalland large-scale aquarium fish culture facilities supplying their customers with tropical fish of both local and foreign origin. Reduction of the risk of mycobacterial infections, aimed at protecting both fish and human population, is of a high topical importance. Introduction of thorough veterinary inspection of imported fish as well as ornamental fish supplied from distributors and aquarist shops should provide a starting point for efforts to achieve this goal.

\section{Původci mykobakteriálních onemocnění akvarijních ryb a jejich význam při infekcích lidí v České republice}

V průběhu let 1995 až 2004 byly při vyšetřování zdravotního stavu akvarijních ryb z Moravskoslezské oblasti ČR izolovány následující mykobakteriální druhy: $M$. fortuitum (Paracheirodon axelrodi, Poecilia sphenops, Hemigrammus rhodostomus, Hyphessobrycon flammeus), M. chelonae (P. axelrodi, Betta splendens, Xiphophorus helleri, Puntius tetrazona), M. kansasii ( $P$. axelrodi, B. splendens), M. simiae (Hyphessobrycon ecuadoriensis) a M. gordonae (P. axelrodi, Colisa lalia, B. splendens, Symphysodon discus). Poprvé bylo z akvarijních ryb izolováno $M$. kansasii a podruhé $M$. simiae, která je třeba respektovat i jako etiologická agens mykobakteriálních nákaz u člověka. Monitoring vodovodních řádů jako možných zdrojů infekcí $M$. kansasii, dodržování hygienických zásad při manipulaci s rybami podezřelými z onemocnění a obsahem akvárií (šneci, voda, rostliny) a zavedení důsledné veterinární kontroly rybích importů, ryb z akvaristických prodejen a od distributorů $\mathrm{z}$ velkochovů by měly minimalizovat mykobakteriální infekce ryb a lidské populace.

\section{References}

ADAMICOVÁ K, FETISOVOVÁ Ž, STRMEŇOVÁ V, MAAROUF Z, ONDREJOVIČ P, MAĎAR R, MELLOVÁ Y 2003: Granulomatous skin disease after exotic injury. Čes- slov Patol 39: 80-84 [in Slovak]

ALCAIDE F, RICHTER I, BERNASCONI C, SPRINGER B, HAGENAU C, SCHULZE-RÖBBECKE R, TORTOLI E, MARTÍN R, BÖTTGER EC, TELENTI A 1997: Heterogeneity and clonality among isolates of Mycobacterium kansasii: Implications for epidemiological and pathogenicity studies. J Clin Microbiol 35: 1959-1964 AMLACHER E 1986: Taschenbuch der Fischkrankheiten. VEB G. Fischer Verlag Jena, 478 p.

ANACKER RL, ORDAL EJ 1959: Studies on the myxobacterium Chondrococcus columnaris. I. Serological typing. J Bact 78: 25-32

ANTONIO DB, SWANSON C, CECH JJ Jr, MAGER RC, DOROSHOV S, HEDRICK RP 2000: Prevalence of Mycobacterium in wild and captive delta smelt. Calif Fish Game 86: 233-243

ARAKAWA CK, FRYER JL 1984: Isolation and characterization of a new subspecies of Mycobacterium chelonei infectious for salmonid fish. Helgolander Meeresuntersuchungen 37: 329-342

ARAKAWA CK, FRYER JL, SANDERS JE 1986: Serology of Mycobacterium chelonei isolated from salmonid fish. J Fish Dis 9: 269-271 
ASTROFSKY KM, SCHRENZEL MD, BULLIS RA, SMOLOWITZ RM, FOX JG 2000: Diagnosis and management of atypical Mycobacterium spp. infections in established laboratory zebrafish (Brachydanio rerio) facilities. Comp Med 50: 666-672

AUSTIN B, AUSTIN DA 1987: Bacterial Fish Pathogens: Disease in Farmed and Wild Fish. Ellis Horwood Ltd, Chichester, $364 \mathrm{p}$.

BATAILlON E, DUBARD R, TERRE U 1897: Un nouveau type de tuberculose. Com Ren Sean Soc Biol 49: 446-449

BOWENKAMP KE, FRASCA S Jr, DRAGHI A, TSONGALIS GJ, KOERTING C, BRAGG RR, HUCHZERMEYER HFAK, HANISCH MAM 2001: Mycobacterium fortuitum isolated from three species of fish in South Africa. Onderstepoort Journal of Veterinary Research 57: 101- 102

BRAGG, RR, HUCHZERMEYER, HFAK, HANISCH, MAM 1990: Mycobacterium fortuitum isolated from three species of fish in South Africa. Onderstepoort Journal of Veterinary Research 57: 101-102

CASSAL M, CASSAL MM 2001: Multicenter study of incidence of Mycobacterium marinum in humans in Spain. Int J Tuberc Lung Dis 5: 197-199

CHAN K, KNAAK T, SATKAMP L, HUMBERT O, FALKOW S, RAMAKRISHNAN L 2002: Complex pattern of Mycobacterium marinum gene expression during long-term granulomatous infection. Proc Natl Acad Sci USA 19: 3920-3925

CSABA GY, KOVÁCS-GAYER E, BEKESI L, TUBOLY S, BANKI M, KÖRMENDI B 1982: Mykobakteriose der Fische. - II Massenerkrankung in einer Macropodus opercularis zucht. Riv It Pisci Ittiop - A.XVII - N.2 : 84-88

DAOUST PY, LARSON BE, JOHNSON GR 1989: Mycobacteriosis in yellow perch (Percaflavescens) from two lakes in Alberta. J Wildl Dis 25: 31-37

De La TORRE C, VEGA A, CARRACEDO A, TORIBIO J 2001: Identification of Mycobacterium marinum in sea-urchin granulomas. Br J Dermatol 145: 114-116

EILERTSEN E 1969: Atypical mycobacteria and reservoir in water. Scand J Resp Dis 50, Suppl. 69: 85-88

ERGENS R, LOM J 1970: Causative agents of fish diseases. Academia, Prague, 383 p. [in Czech]

FASSATIOVÁ O 1979: Moulds and filamentous fungi in technology. SNTL, Praha, 211 p. [in Czech]

GAUTHIER DT, VOGELBEIN WK, OTTINGER CA 2004: Ultrastructure of Mycobacterium marinum granuloma in striped bass Morone saxatilis. Dis Aquat Org 62: 121-132

HOWARD JB, KLAAS J, RUBIN SJ, WEISSFIELD AS, TILTON RC 1987: Clinical and pathogenic microbiology. C.V. Mosby, St. Louis, Missouri.

IPPEN R 1964: Vergleichende pathologische Untersuchungen über die spontane und experimentelle Tuberculose der Kaltblüter. Akademie Verlag Berlin, 90 p.

JAHNEL J 1940a: Spontaninfektionen mit saürefesten Stäbchen bei Fischen. (Neue Beobachtungen über Fischtuberkulose). Wien Tierärztl Mschr 27: 289-302

JAHNEL J 1940b: Die Fischtuberkulose. Wschr Aquar Terrark 37: 317-321

KAUSTOVÁ J 2003: Aquaristics and mycobacterium infections. Akvárium, No 3:30-32 [in Czech]

KAUSTOVÁ J, CHMELÍK M, ETTLOVÁ D, HUDEC V, LAZAROVÁ H, RICHTROVÁ S 1995: Disease due to Mycobacterium kansasii in the Czech Republic: 1984-89. Tubercle and Lung Disease 76: 205-209

KAUSTOVÁ J, OLŠOVSKÝ Ž, KUBÍN M, ZATLOUKAL O, PELIKÁN M, HRADIL V 1981: Endemic occurrence of Mycobacterium kansasii in water-supply systems. J Hyg Epid Mikrob Immun 25: 24-30

KRÜMMEL A, SCHRÖDER KH, KIRCHBACH GV HIRTZEL F, HÖVENER B 1989: Mycobacterium simiae in Deutschland. Zbl Bakt 271: 543- 549

KULLAVANIJAYA P 1999. Atypical mycobacterial cutaneous infection. Clin Dermatol 19: 153-158

LANSDELL W, DIXON B, SMITH N, BENJAMIN L 1993: Isolation of several Mycobacterium species from fish. J Aquat Anim Health 5: 73-76

LOM J, DYKOVÁ I 1992: Protozoan Parasites of Fishes. Developments in Aquaculture and Fisheries Science. Elsevier Amsterdam-London-New York-Tokyo, 315 p.

LUCKÝ Z 1978: Veterinary care in fish culture. Ústav veterinární osvěty Pardubice, 205 p. [in Czech]

LUCKÝ Z 1982: Methodical guidelines on fish disease diagnostics. SPN Praha, 150 p. [in Czech]

LUCKÝ Z, VANĚK J 1962: Tuberculosis of aquarium-kept fish. Acta universitatis agriculturae, Brno 10 (31): $127-$ 131 [in Czech]

MAJEED SK, GOPINATH C 1983: Cutaneous tuberculosis in the carp, Cyprinus carpio L. J Fish Dis 6: $313-316$

MARTÍNKOVÁ I, ŠEBÁKOVÁ H, PELIKÁN M, ZATLOUKAL O 2001: Endemic incidence of infectious cause by Mycobacterium kansasii in the Karviná district in 1968-1998. Epidemiol Microbiol Imunol 50: 165-180 [in Czech]

MÁTLOVÁ L, FISCHER O, KAZDA J, KAUSTOVÁ J, BARTL J, HORVÁTHOVÁ A, PAVLÍK I 1998: The occurrence of mycobacteria in invertebrates and poikilothermic animals and their role in the infection of other animals and man. Vet Med Czech 43: 115- 132 [In Czech]

NIGRELLIRF, VOGEL H 1963: Spontaneous tuberculosis in fishes and in other cold-blooded vertebrates with special reference to Mycobacterium fortuitum Cruz from fish and human lesions. Zoologica (New York) 48: 131

NOGA EJ, WRIGHT JF, PASARELL L 1990: Some unusual features of mycobacteriosis in the cichlid fish Oreochromis mossambicus. J Comp Pathol 102: 335-344 
PALOMO C, SANTOS-JUANES J, GALACHEB C, ROMERO F, TELENTI M, SANCHES del RIO, JA 2001: Lymphocutaneous syndrome due to Mycobacterium marinum in young aquarium enthusiast. Infect Microbiol Clin 19: 506-507

PARISOT TJ, WOOD JW 1966: Fish mycobacteriosis (tuberculosis). U.S. Bur Sport Fish Wildl FDL-7: 2 p.

PICARDEAU M, PROD'HOM G, RASKINE L, LEPENNEC MP, VINCENT V 1997: Genotypic characterization of five subspecies of Mycobacterium kansasii. J Clin Microbiol 35: 25-32

RICHARDS R 1977: Diseases of aquarium fish. 2: Skin diseases. The Veterinary Record 101: 132-135

ROBERTS RJ, SHEPHERD CJ 1997: Handbook of Trout and Salmon Diseases. Fishing News Books, Third Edition, London, 179 p.

RUBIN E, FARBER JL 1988: Patology. J.B. Lippincot, Philadelphia, 1576 p.

SANTOS NMS, VALE A, SOUSA MJ, SILVA MT, SANTOS NMS, SANTOS NM, VALE A 2003: Mycobacterial infection in farmed turbot Scophthalmus maximus. Dis Aquat Org 52: 87-91

SCHRÖDER KH, KAZDA J, MÜLLER K, MÜLLER HJ 1992: Isolation of Mycobacterium simiae from the environment. Zbl Bakt 277: 561- 564

SHAMSUDIN MN, TAJIMA K, KIMURA T, SHARIFF M, ANDERSON IG 1990: Characterization of the causative organism of ornamental fish mycobacteriosis in Malaysia. Fish Patology 25: 1-6

ŠLOSÁREK M, JANOTA J 1990: Effectiveness of the water treatment process on the removal of conditioned pathogenic mycobacteria. Vodní Hospodářství 1: 40-42 [in Czech]

TALAAT AM, TRUCKSIS M, KANE AS, REIMSCHUESSEL R 1999: Pathogenicity of Mycobacterium fortuitum and Mycobacterium smegmatis to goldfish, Carassius auratus. Vet Microb 66: 151- 164

TORTOLI E, BARTOLONI A, BOZZETTA E, BURRINI C, LACCHINI C, MANTELLA A, PENATI V, SIMONETTI MT, GHITTINO C 1996: Identification of the newly described Mycobacterium poriferae from tuberculous lesions of snake-head fish (Channa striatus). Comp Immunol Microbiol Infect Dis 19: 25-29

VAN DUIJN C 1981: Tuberculosis in fishes. Journal of Small Animal Practice 22: 391-411

VASILOVÁ Z 1988: Recovery of atypical mycobacteria in aquarium culture. In: Proceedings of the technical seminar of young specialists in veterinary laboratory and clinical diagnostics. Praha, 7-8.9.1988, ÚSVÚ, pp. 11-12 [in Czech]

WAYNE LG, SRAMEK HA 1992: Agents of newly recognized or infrequently encountered mycobacterial diseases. Clinical Microbiology Reviews 5: 1-25

WOLKE RE 1975: Pathology of bacterial and fungal diseases affecting fishes. In: RIBELIN, WE, MIGAKI, G (Ed.): The Pathology of Fishes. University of Wisconsin Press, Madison, Wisconsin, pp. 33-116

WOLKE RE, STROUD RK 1978: Piscine mycobacteriosis. In: MONTALI, RJ (Ed.). Proc.Symp. Mycobacterial Infections in Zoo Animals. Smithsonian Institution Press, Washington D.C., pp. 269-275

WOOD JW, ORDAL EJ 1958: Tuberculosis in Pacific salmon and steelhead trout. Fish Comm Ore Contr No. 25: $1-38$

WU TS, CHIU CH, SU LH, LEE MH, CHIANG PC, KUO AJ, WU TL, LEU HS 2002: Mycobacterium marinum infection in Taiwan. J Microbiol Immunol Infect 35: 42-46 
Plate VII

Řehulka J. et al.: Causal Agents ... pp. 251-258

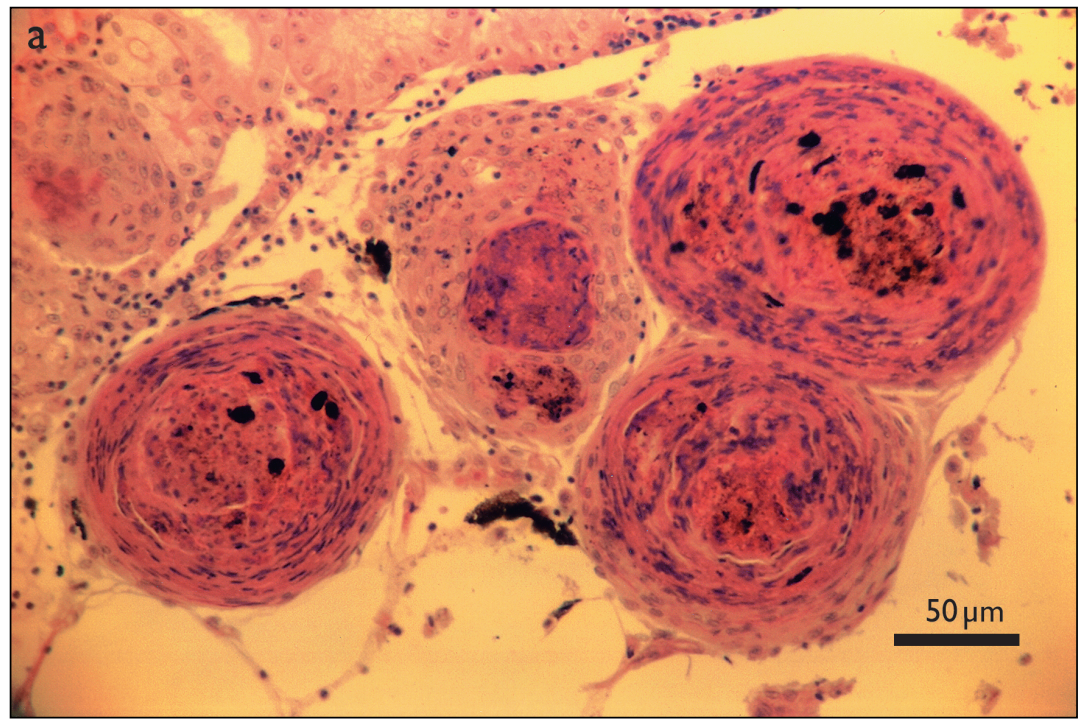

Fig. 1. Systemic Mycobacterium simiae infection in the Columbian tetra, Hyphessobrycon ecuadonensis. (abc) Granulomas in the affected kidney (haematoxylin and eosin, Figures a and b, Ziehl-Neelsen's method, Fig. c). (d) The mycobacteria stain within the granuloma (Ziehl-Neelsen method).

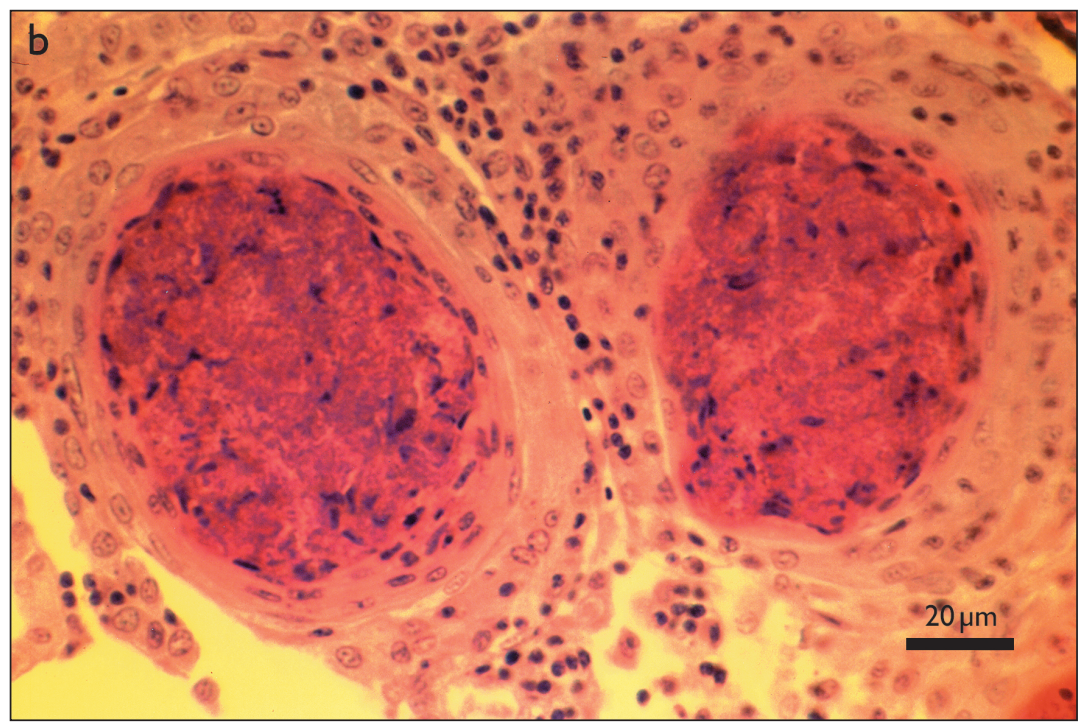


Plate VIII
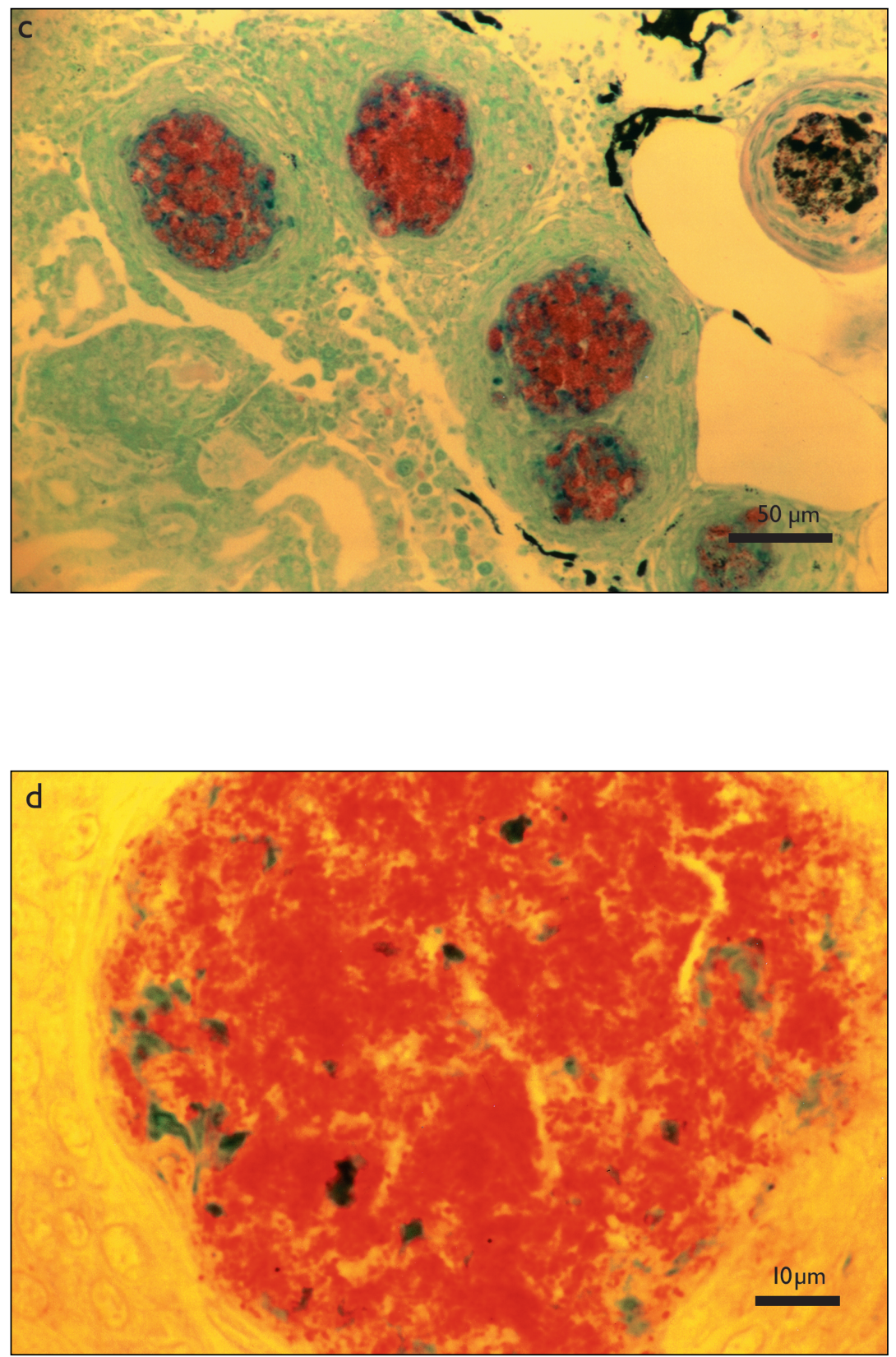